\title{
Embedding Environmental Sustainability Competencies in Human Capital Training and Development
}

\author{
Anthony Kola-Olusanya \\ Department of Geography, \\ College of Management and Social Sciences \\ Osun State University, Nigeria
}

\section{Doi: $10.5901 / m j s s .2013 . v 4 n 4 p 65$}

\begin{abstract}
This article explores the dynamics of environmental sustainability and its integrative ability to shape human resource development (HRD) training. Since HRD is about human capital training and development, Jithendran and Baum (2000) asserted that HRD holds the key to sustainability. They argued that since development requires a higher level of quality, and preservation requires attitudes, sensitivities, and practice that can promote environment from the local to the international, both development and preservation falls strictly within the HRD domain. This paper demonstrates that opportunity exists to integrate and orientate sustainability practices in developing human capital. This paper sustains that learning and developmental processes are appropriate mechanisms to facilitate corporate sustainability and pro-environmental practices, which in turn can create an opportunity to develop intellectual capital and by implication source of value creation as well sustainable resource use.
\end{abstract}

Keywords: Sustainability, environmental learning, human resource development, organizational citizenship

\section{Introduction}

The twenty first century poses new challenges for all societies, especially with the attendant consequences of business on the environment becoming more obvious due to destruction of ecosystems and impending global warming. As a result, there is a general recognition that the profligate, extravagant and inequitable nature of the current patterns of development, when projected into the not too distant future, may lead to biophysical impossibilities (Ratner, 2004; Scott \& Gough, 2004a, 2004b). Given this understanding, Cummings (2010) argued that the survival of the earth hinges on a race between disaster and education, of which certainly knowledge development and training holds a key to that outcome. Especially considering the increase in environmental awareness and the need for organizations to act in an environmentally responsible manner for reasons ranging from alignment with organizational values, enhance reputations, and the ability of engage in cost savings.

To achieve this outcome, there is a general agreement that a sustainable organization will need to incorporate learning in relation to environment and sustainability as an intrinsic and continuous part of the social responsibility process (Gough \& Scott, 2006; Rickinson, 2006). As noted by Garavan and McGuire (2010) "prior research highlights that when it comes to ... sustainability, HRD practitioners are not particularly interested in and may not possess the skills to play a significant role in promoting sustainability goals ...in organizations"(489). Herein lies the need for integration environmental sustainability within human resource development (HRD). Herein lies the need for integration environmental sustainability within human resource development (HRD). According to Bierema (2009) although

CSR goes hand-in-hand with sustainability. The atrocities of corporate crime have hurt countless people who put trust in their leaders. HRD professionals have escaped unscathed by ethical scandals such as Enron or the recent collapse of the financial markets, thanks to the world's preoccupation with profitability and performance. ... HRD needs to incorporate responsibility and sustainability into its repertoire (p. 88).

This argument reinforces the importance of environment sustainability intervention in corporate organizations.

This point is further buttressed by Lockwood (2004) who argued that "the current environment is seeing pressure and the mainstreaming HRD is increasingly being called on to support these goals through well-managed programs, policies, and practices" (cited in Bierema, 2009, pg. 89). Since the deployment of HRD tools and interventions can cause organizations and its employees to learn creatively and initiatively to respond to the challenge of making products and 
processes greener means. Building on this premise, this article explores the dynamics of environmental sustainability and its integrative ability to shape human resource development (HRD) training. This paper also suggests a comprehensive and strategic approach to HRD, catering to the training, education and development needs, which reflect willingness to protect the environment and the corporate organization.

\section{Understanding the Nature of Human Resources in Development}

Human resource development (HRD) is an emerging field of practice and research. Broadly concerned with the humans in organizations, HRD has historically been focused on issues related to the development of workers and the organization with regard to training, career development, and organization development (McLagan, 1989). According to McLean and McLean (2001: 322) "human resource development is any process or activity that, either initially or over the long term, has the potential to develop adults' work-based knowledge, expertise, productivity, and satisfaction ... for the benefit of ... community, nation, or ultimately the whole of humanity." Further, human resources development describes a framework for the expansion of human capital within an organization and the structure that allows for individual development potentially satisfying the organization's goals (McLagan, 1989).

In this sense, the development of the individual will benefit both the individual and the organization. This framework views employees or members within an organization as an asset to the enterprise whose value will be enhanced by development. Its primary focus is on growth and employee development while emphasizing development of individual potential and skills (Holton II \& Trott Jr, 1996). It involves a combination of training and education that ensures the continual improvement and growth of both the individual and the organization. In relation to training and education, the framework focuses on the organization's competencies at the first stage, training, and then developing the employee, through education, to satisfy the organization's long-term needs and the individuals' career goals and employee value to their present and future employers. As suggested by Kelly $(2001 ; 2006)$ it is largely dependent on the capacities of individuals' access to education given its nature as a medium that drives the process between training and learning.

Accordingly Nadler (1984) argued that human resources development is not an object that can be easily defined, but a series of organized processes, with a specific learning objective. Kelly $(2001 ; 2006)$ human resources development can be defined simply as developing the most important section of any business its human resource by, "attaining or upgrading the skills and attitudes of employees at all levels in order to maximize the effectiveness of the enterprise." Therefore human resources development could be in-room group training, tertiary or vocational courses or mentoring and coaching by senior employees with the aim for a desired outcome that will develop the individual's performance. An apprentice will step through the development process to become a tradesman in their field as will a white-collar trainee to become a professional in their field. Training will allow the individual to complete a task within their field today, training provides, maintains and enhances skills to perform the job (Nadler, 1984).

A successful Human resources development program will prepare the individual to undertake a higher level of work, through organized learning over a given period of time, to provide the possibility of performance change (Nadler, 1984). Underscoring this position, Wirtenberg et al (2007) noted that human resources (HR) are viewed as key factor in an organization's ability to build and sustain competitive advantage, as such its development is critical in business and management of corporations and companies.

Research efforts (see for example, Hitchcock \& Willard, 2006; Loosey, Meissinger, \& Ulrich, 2005; Wirtenberg et al., 2007) have pointed out that these key factors are at the core of an organization's development and strategic leadership. In the same vein, Hitchcock and Willard (2006) maintained that many in HR are not conversant with sustainability and this has led to many organization making implementation mistakes which could have been avoided (Wirtenberg et al., 2007). Therefore the critical role for HR field is the development of individual competencies, collaborative strategies and organizational capability capable of supporting organization's sustainability efforts (Wirtenberg et al., 2007).

\section{Economic Growth and Environment Degradation}

With the global human population at seven (7) billion, the attendant consequences of environmental degradation and the depletion of natural resources underscore the need for sustainable management and the protection of the planet. As Freis-Tordini $(2003,2005)$ explains, stress to the environment includes such things as the decrease in varieties of animal and plant species, increase in floods and fires and increase in carbon dioxide levels in the atmosphere effecting climates and the ozone layer. The care and protection of the environment is necessary, without such care and protection it will be 
difficult to abate the continued depletion of world's lands and waterways, as well as the reduction of global carbon dioxide pollution.

Realization of the dangers associated with increases in human population, worsening environmental degradation and resource shortages have served as a wake-up call that there is need for change in our approach to development (Bartlett, 2006). A greater awareness of the problem ensued from the World Conference on Environment and Development (WCED) report, Our Common Future. This report called for economic development that allows present generations to meet their needs without compromising the ability of future generations to cater to theirs (WCED, 1987). The report also raised awareness to the substantial nature of the problems the global environment faces, as well as the untold hardships people have experienced with growing intensity throughout the world, especially in the global South.

Despite significant progress towards sustainable development, increased extraction of natural resources, accumulation of waste and concentration of carbon dioxide emissions have continued to place considerable stress on the global environment. Research evidences in the field of environmental economics and development point to the growth in global economic activities as being responsible for current levels of environmental degradation. Mclnnes (2002) caution that if economic growth continues to be based on traditional, environmentally damaging activities, the world will not be able to sustain economic growth indefinitely, without running into resource constraints or despoiling the environment beyond repair. For others knowledge is an important precursor to one's willingness to take action. The underlying assumption here is that if people are aware of the need for and the ways of protecting the environment they will act to preserve it (Kola-Olusanya, 2009). The importance of knowledge and the impact of lack of knowledge in the decisionmaking process have been demonstrated in numerous studies. Monroe and Kaplan (1988) identify the important elements required for transforming learning and knowledge into action. The action is also intended to achieve a specific positive environmental outcome, either small or large" (Schusler \& Krasny, undated). Among them are: knowledge of environmental and sustainability issues, a sense of responsibility and commitment, knowledge of action strategies that help resolve issues, locus of control and empowerment.

\section{Conceptual Building Blocks: The Sustainability Argument}

The increasing consequences of global environmental and natural disasters such as Tsunami, hurricane, famine, desertification, global warming and climate change on the planets' health has continued to raise the importance of living sustainably in harmony with the earth. According to the sustainable development principle, depleting the planet in the name of economic development that seeks to maximize economic production, only to deny the future generations the resources bequeathed to the present generation as well as the future generations of the earth's inhabitants, is unacceptable (Cross, 2002; Eneh, 2009).

In order to achieve the stated objective of meeting current needs without compromising the needs of future generations, sustainable development sets out to achieve a balance between economic, social and ecological objectives. This balance is based on the understanding that sustainable economic and social development is critically dependent on the health of the ecological system upon which this development is based (Barbour \& Sowman, 2004). On the qualitative angle, sustainable development therefore involves, a broad view of social, environmental and economic outcomes; a long-term perspective, concerned with the interests and rights of future generations as well as of people today; an inclusive approach to action, which recognizes the need for all people to be involved in the decisions that affect their lives. Other scholars like Vaughan and Bearse (1981) viewed sustainability as a qualitative change, that is, not only economical change, but institutional, social and environmental changes as well. Such change, according to Munier (2005: 19), requires a decrease in consumption rates of non-essential items, a decrease in water usage and the use of recycled water many times over, a reduction in the consumption of paper and board products and the use of fiber produced from trees in planted forests. Based on this definition, sustainability could be the destination, the end-goal, while sustainable development is a means of getting there.

It requires that natural capital remains intact; this means that the source and sink functions of the environment should not be degraded. Therefore, the extraction of renewable resources should not exceed the rate at which they are renewed, and the absorptive capacity to the environment to assimilate wastes should not be exceeded. Environmental sustainability outlines pragmatic operational methods to reverse environmental damage and reduce poverty. Its aim is that the (aggregate) environmental impacts shall not impair the functioning of resource regenerative systems and waste assimilative systems, and the use of non-renewable resource is compensated for by equivalent increases in supplies of renewable or reproducible substitutes. To achieve sustainability requires learning, how to manage renewable resources for the long term, reduce waste and pollution Goodland (1997) further stresses that we must learn how to use energy and material with scrupulous efficiency; we must learn how to use solar energy in all its forms, and we must invest in 
repairing the damage, as much as possible, done to the earth in the few decades by unthinking industrialization and violence in many parts of the globe. (p. 85)

Heuristically, one of the principles of sustainability or sustainable development is the promotion of behavioural change. It calls for creating some sustainable measures of protecting, conserving and developing the existing natural resources.

Within the business world, sustainability is viewed as conceptual framework that recognizes that a viable relationship exists between an organization's economic performance and its environmental and social activities. It is primarily a dynamic approach built on integrated framework used to frame business strategy as a dialogue which helps managers to reorient their business as well as linking their capabilities and employees capabilities/competencies to align them with organizational resources (Christofi \& Sisaye, 2008). As Wheeler, Colbert, and Freeman (2003: 17) have stated, sustainability is "an ideal toward which society and business can continually strive, the way we strive is by creating value, creating outcomes that are consistent with the ideal of sustainability along social environmental and economic dimensions". The problem comes when the corporation has to develop the processes and implement strategies to meet the corporate challenge of corporate sustainable development. Therefore, sustainability from the business and corporate perspective suggests attending to and combining the important areas of environment, economics, and (social) equity- also known as the "Three EEEs" and the "Triple Bottom Line" (Willard, 2010).

\section{Mainstreaming Environmental Sustainability into HRD - A Model}

Sustainable development as a compelling idea is concerned with how business can contribute to some of the most significant challenges that the world faces today - from climate change and biodiversity, to working conditions and health amongst the poorest in the world. Today, amid the third industrial revolution, leading companies are superficially rediscovering their consummative patterns in the face of potential environmental degradation and "move[ing] past these old-wave principles of economic reproduction by informationalizing the production process and making it more environmental" (Luke, 2001: 316). The enhanced corporate profits, enlightened public image, and increased productivity, which stems from a "green" corporate mandate, overshadow this assumed affirmative ecological progress. To this extent, training in social and environmental dilemmas can build skills which are relevant in many situations - from leadership and team-working, to negotiating and problem-solving. A sustainable development perspective informs the way people think and act in critical business areas; hence companies are expected to continually enhance their workforces' skills to respond to the emerging demands of stakeholders (for example, customers, investors and society) as a whole requirements that holds the key to changing the ways people live and work.

Human resource development (HRD) as an emerging field of practice and research is concerned with the humans in organizations, and issues related to the development of workers and the organization with regard to training, career development, and organization development (McLagan, 1989). It involves a combination of training and education that ensures the continual improvement and growth of both the individual and the organization. In relation to training and education, the framework focuses on the organization's competencies at the first stage, training, and then developing the employee, through education, to satisfy the organization's long-term needs and the individuals' career goals and employee value to their present and future employers. As noted by Madsen \& Ulhøi (2001) the education and training of the workforce is an essential ingredient in promoting and implementing environmental management practices in business organisations. However, even in leading companies, little information has been available on how environmental management practice and related educational and training requirements are translated into the provision of training courses by educational institutions.

A successful Human resources development program will prepare the individual to undertake a higher level of work, through organized learning over a given period of time, to provide the possibility of performance change. According to Chalofsky (2007) HRD has evolved from a primarily practice-driven field to a body knowledge with an interdisciplinary foundation. Since individual, community, national, and global well-being depend on using the resources and diverse talents and capabilities of the broadest possible spectrum of humanity. As such environmental competencies can only be attained if environmental sustainability is mainstreamed into the broader training programs. HRD leaders such as McLean (2001), Bates (2003), and others have proposed that HRD should take the leading role in economic development and workplace learning, by building a custom-made process with each organization choosing its own specific ambition and approach regarding corporate sustainability. This should meet the organization's aims and intentions, and be aligned with the organization strategy, as an appropriate response to the circumstances in which the organization operates.

Within the tenets of training and human capital development, organizations should incorporate sustainability as the driver for motivating employees as well as attract new employees, who have concern for the environment and for their 
future lifestyles. This suggests therefore that mainstreaming process should commence with the introduction and integration of sustainable development issues from the outset into the recruitment process, especially in job descriptions and assessment materials. However, the main challenge at an organization or corporate level for HR managers is not integration and introduction but clarifying the competencies required to deliver the company's strategy, introduction of sustainable development within their organizations as well as to cope with changing competitive circumstances. To do this extent the company/organization is expected to identify key sustainable development competencies, such as social and environmental issues within employee training and development programmes at all levels, from technical health and safety considerations on the lower levels, to strategic sustainability issues at executive management and board level which could be included in induction materials.

As a corollary, HR managers expectedly should ensure that training programmes consider the identification and application of business risks and opportunities based on sustainable development criteria as effective means of building sustainable development competencies for different business functions and different levels of seniority. Given that this is considered a powerful lever for promoting behavioural change, it is important for organizations to fold sustainability criteria into their management system. In other words, organization must draw a link between HRD and sustainability to underscore human capital development by re-evaluating job description to reflect the organisation sustainability criteria. In particular, incorporating sustainability competencies into training strategies and tactics should focus on organizationtailored value-added strategies that cannot be easily imitated but capable of re-orienting workers to changes over time. Success in the larger context will largely depend on corporation's ability at identifying the most effective means of building these competencies, whether through formal training programmes.

\section{Conclusion and Implications for HRD Practice}

In an age when human capital is being recognized both inside and outside the realm of the HR, mainstreaming sustainability competencies will enable professionals to hone their skills as well as prepare for the business and organizational challenges that have yet to be defined. Human resource practitioners are considered the keepers of the flame when it comes to corporate culture, team building and change management processes. Therefore, keeping true to the corporate sustainability values compass can be a critical guidepost towards gaining from the bottom-line benefits of incorporating sustainability into their DNA. An environmentally conscious HR team can take the lead or partner with other executives to work cross-functionally to integrate sustainability objectives into how business gets conducted. As McGuire (2010) maintained, in developing an environmentally responsive role, the training of management and staff provides a powerful mechanism for disseminating positive messages regarding the promotion of environmental issues. For example, training modules and workers learning programmes should infuse and integrate sustainability concepts into the training manuals. Hence, workers' training should focus on long-term competency development and focused on capturing and developing employees' knowledge.

Azzone and Noci (1998) noted the importance of training courses aimed at raising employee awareness of green issues as a prerequisite to fostering environmental innovation in organization. This points to the possible gains for HRD practice, which revolves around the idea that, what is good for the environment, workers, and the community, is also good for the financial performance of the business and sound stewardship of the social and environmental conditions for economic growth (Whitaker, 2007). This paper demonstrates that opportunity exists to integrate and orientate sustainability practices in developing human capital. An integrative and infusion approach within training curricula would provide opportunity for continuous learning and education that leads to productive lives of self-fulfillment as well as develop critical thinking while acting ethically with sensitivity to both the human community and the biosphere. For instance, as Egri and Hornal (2002) have demonstrated within the HRM context, a strategic HRM approach that incorporated environmental and sustainability objectives have without doubt, significantly enhanced perception of organizational performance.

To conclude, this paper sustains that learning and developmental processes are appropriate mechanisms to facilitate corporate sustainability practices, which in turn can create an opportunity to develop intellectual capital and by implication source of value creation. Because, saving nature and environmental resources will require saving the people first through education by embedding environmentalism as a core competence so that people can learn about how to actively protect nature and thereby possessing shared ownership of natural resources and the environment. The expectation here is that an environmentally employee will experience an improvement in their affective commitment towards an organization and its core values. Affective commitment is defined as "identification with, involvement in, and emotional attachment to the organization" (Allen \& Meyer, 1996; Rego, Leal, Cunha, Faria, \& Pinho, 2010), which lead to lower employee turnover (Meyer, Hersecovich, \& Topolnytsky, 2002). Implicit is that it reduces hiring costs by attracting 
better quality applicants with competencies in environmental sustainability, capable of mitigating potential risks by enhancing corporate social responsibility as well as brand equity and reputation allowing firms to weather difficult times (Nastanski, 2012). This on the long run holds the possibility of benefitting organization positively and by implication boosting HRD practices. Finally, environmental and sustainability conscious human resource professionals could help deepen their experience, by understanding their role in sustainability and CSR and how they can foster an environment that embeds a CSR ethic in "the way we do business around here" (Industry Canada, 2009).

\section{References}

Allen, N. J., \& Meyer, J. D. (1996). Affective, continuance, and normative commitment to the organization: An examination of construct validity. Journal of Vocational Behaviour, 49, 252-276.

Azzone, G., \& Noci, G. (1998). Seeing ecology and green innovations as a source of change. Journal of Organizational Change Management, 11(2), 94-112.

Barbour, T., \& Sowman, M. (2004). Eastern Cape Province growth and development plan 2004-2014: Mainstreaming environmental sustainability considerations into PGDP. University of Cape Town, Cape Town.

Bates, R. (2003). Human resource development objectives. In M. Marquardt (Ed.), Encyclopaedia on Life support Systems. Paris, France: UNESCO.

Bierema, L. L. (2009). Critiquing human resource development's dominant masculine rationality and evaluating its impact, from http://hrd.sagepub.com/cgi/content/abstract/8/1/68

Chalofsky, N. (2007). The seminal foundation of HRD: People, leaning and organizations. Human Resource Development International, $18,431-442$.

Christofi, P., \& Sisaye, S. (2008). Is there a relationship between sustainable reporting and organizational performance? An examination of corporate performance indicators. Retrieved August 23, 2010, from http://www.decisionsciences.org/ Proceedings/ DSI2008/docs/103-2584.pdf

Cross, N. (2002). Sustainable Development. Developments: The International Magazine, 18.

Cummings, G. (2010). The Leadership factor: Implementing sustainability in higher education. Retrieved September 3, 2010, from http://secondnaturebos.wordpress.com/2010/07/06/the-leadership-factor-implementing-sustainability-in-higher-education/

Egri, C. P., \& Hornal, R. C. (2002). Strategic environmental human resource management and perceived organizational performance: An exploratory study of Canadian manufacturing sector. In S. Sharma \& M. Starik (Eds.), Research in corporate sustainability: The evolving theory and practice of organization in the natural environment. Northampton, MA: Edward Elgar.

Eneh, O. C. (2009). The Chemist and Environmental Sustainability. Paper presented the Repositioning African Business and Development for the 21st Century 10th Annual Conference IAABD.

Freis-Tordini, K. (2003, 2005). Environmental Protection for Social Equality. Retrieved February 1, 2008, from $\mathrm{http}: / /$ www.haguepeace.org/files/morePeaceLessons/Environmental\%20Protection $\% 20$ for $\% 20$ Social\%20Equality\%20(Kathl een $\% 20$ USA).pdf.

Garavan, T. N., \& McGuire, D. (2010). Human resource development and society: Human resource development's role in embedding corporate social responsibility, sustainability, and ethics in organizations. Advances in Developing Human Resources, 12(487507).

Goodland, R. (1997). Biophysical and objective environmental sustainability. In A. K. Dragun \& K. M. Jakobson (Eds.), Sustainability and global environmental policy: New perspectives (pp. 63-96). Cheltenham, UK: Edward Elgar.

Gough, S., \& Scott, W. (2006). Promoting environmental citizenship through learning: Toward a theory of change. In A. Dobson \& D. Bell (Eds.), Environmental citizenship (pp. 263-286). Cambridge, MA: MIT Press.

Hitchcock, D., \& Willard, M. (2006). The business guide to sustainability: Practical strategies and tools for organization. London, UK: Earthscan.

Holton II, E. F., \& Trott Jr, J. W. (1996). Trends Toward a Closer Integration of Vocational Education and Human Resources Development. Journal of Vocational and Technical Education, 12(2), 7.

IC. (2009). Human Resources for Sustainability. Retrieved March 20, 2012, from http://www.ic.gc.ca/eic/site/csrrse.nsf/eng/h rs00552.html

Jithendran, K. J., \& Baum, T. (2000). Human resources development and sustainability - The case of Indian tourism. International Journal of Tourism Research, 2, 403-421.

Kelly, D. (2001). Dual perceptions of HRD: Issues for policy: SME's, other constituencies, and the Contested definitions of human resource development. Retrieved June 10, 2009, from http://ro.uow.edu.au/artspapers/26

Kelly, D. (2006). Human Resource Development: For Enterprise and Human Development. Retrieved May 12, 2009, from http://ro.uow.edu.au/artspapers/114.

Kola-Olusanya, A. (2009). Environmental sustainability: Understanding young adults' learning, thinking, and actions. Berlin, Germany: Lambert Publishers.

Lockwood, N. R. (2004). Corporate social responsibility: HR's leadership role. Retrieved September, 2011, from http://findarticles.com/p/articles/mi m3495/is 12 49/ai n8583189

Loosey, M., Meissinger, S., \& Ulrich, D. (2005). The future of human resource management. Hoboken, NJ: John Wiley and Sons Inc. 
Luke, W. T. (2001). SUVs and the Greening of Ford: Reimaging Industrial Ecology as an Environmental Corporate Strategy in Action. Organization and Environment, 14(3), 311-335.

Madsen, H., \& Ulhøi, J. P. (2001). Greening of human resources: environmental awareness and training interests within the workforce. Industrial Management \& Data Systems, 101(2), 57-65.

McGuire, D. (2010). Engaging Organizations in environmental change: A greenprint for Action. Advances in Developing Human Resources, 12(3), 508-523.

Mclnnes, G. (2002). European Environment Agency: Annual report 2002. Retrieved Feb 10, 2008, from http://reports.eea.europa.eu /corporate_document_2004_1/en/Annual_report_2002.pdf

McLagan, P. (1989). Models for HRD practice. Alexandria, VA: American Society for Training and Development.

McLean, G. (2001). Human resource development as a factor in the inevitable move to globalization. Paper presented at the Academy of Human Resource Development 2001 Conference, Bowling Green, $\mathrm{OH}$.

McLean, G. N., \& McLean, L. (2001). If we can't define HRD in one country, how can we define it in an international context? Human Resource Development International,, 4(3), 313 - 326.

Meyer, J. D., Hersecovich, S. L., \& Topolnytsky, L. (2002). Affective, continuance, and noirmative commitment to the organization: A meta analysis of antecedents, correlates, and consequences. Journal of Vocational Behaviour, 61, 20-52.

Monroe, M. C., \& Kaplan, S. (1988). The effects of issue investigation and action training on environmental behavior in seventh grade students. Journal of Environmental Education, 19(3), 38-41.

Munier, N. (2005). Introduction to sustainability: Road to a better future. Ottawa, Canada: Springer.

Nadler, L. E. (1984). The Handbook of Human resources Development. New York: John Wiley and Sons.

Nastanski, M. (2012). Leveraging sustainable development to increase brand value and profitability. Paper presented at the International Journal of Arts and Social Sciences: Multidisciplinary Conferences, University of Nevada, Las Vegas.

Ratner, B. D. (2004). Sustainability as a dialogue of values: Challenges to the sociology of development. Sociological Inquiry, 74(1), 5969.

Rego, A., Leal, S., Cunha, M. P., Faria, J., \& Pinho, C. (2010). How the perceptions of five dimensions of corporate citizenship and interinconsistencies predict affective commitment. Journal of Business Ethics(94), 107-127.

Rickinson, M. (2006). Researching and understanding environmental learning: Hopes for the next 10 years. Environmental Education Research, 12(3-4), 445-457.

Schusler, T. M., \& Krasny, M. E. (undated). Youth participation in local environmental action: Integrating science and civic education. Retrieved January 1, 2008, from www.gardenmosaics.cornell.edu/pgs/aboutus/materials/Youth_Participation.pdf

Scott, W., \& Gough, S. (Eds.). (2004a). Key issues in sustainable and learning: a critical review. London: Routledge Falmer.

Scott, W., \& Gough, S. (Eds.). (2004b). Key issues in sustainable development and learning: a critical review. London: Routledge Falmer.

Vaughan, R., \& Bearse, P. (1981). Federal economic development programs: A framework for design and evaluation. In R. Friedman \& W. Schweke (Eds.), Expanding the opportunity to produce: Revitalizing the American economy through new enterprise development (pp. 309). Washington D. C.: Corporation for Enterprise Development.

WCED. (1987). Our common future. Oxford: Oxford University Press.

Wheeler, D., Colbert, B., \& Freeman, R. E. (2003). Focusing on value: Reconciling corporate social responsibility, sustainability and a stakeholder approach in a network world. Journal of General Management, 28(3), 1-29.

Whitaker, D. (2007). Are sustainability and human capital management so very different? Retrieved November 16, 2010, from http://www.personneltoday.com/articles/2007/11/05/43085/are-sustainability-and-human-capital-management-so-very.html

Willard, B. (2010). CSR efforts and employee engagement drive business results. Retrieved November 14, 2010, from http://sustainabilityadvantage.com/

Wirtenberg, J., Harmon, J., Fairfield, K. D., \& Russel, W. G. (2007). HR's role in building a sustainable enterprises: Insights from some of the world's best companies. Human Resource Planning, 30(1), 10-20. 
